\title{
Enhanced productivity of serine alkaline protease by Bacillus sp. using soybean as substrate
}

\author{
Saurabh, S., Jasmine, I., Pritesh, G. and Rajendra Kumar, S.* \\ Department of Microbiology, University of Delhi South Campus \\ Benito Juarez Road, New Delhi - 110021 \\ E-mail: rksmicro@hotmail.com or rksmicro@yahoo.co.in
}

\begin{abstract}
The growth and protease production by Bacillus sp. (SBP-29) was examined for poultry processing industries. The maximum protease activity was $3028 \mathrm{U} / \mathrm{mL}$ using $1.5 \%(\mathrm{w} / \mathrm{v})$ of soybean meal as substrate. Soybean meal is an inexpensive and readily available, thus it can be used as the cost effective crude material for the production of an extracellular protease. Inorganic nitrogen sources proved to be less favorable, for protease production as strong catabolic repression was observed with ammonium ions. A maximum of $3208 \mathrm{U} / \mathrm{mL}$ of protease was produced in $18 \mathrm{~h}$ in a $10 \mathrm{~L}$ bioreactor. The enzyme has temperature and $\mathrm{pH}$ optima of $60^{\circ} \mathrm{C}$ and 9.5 respectively. However, the temperature stability range is from $20-90{ }^{\circ} \mathrm{C}$ and $\mathrm{pH}$ stability range is from $6.0-12.0$. The protease was completely inhibited by phenylmethylsulfonyl fluoride (PMSF) and diodopropyl fluorophosphate (DFP), with little increase (10-15\%) in the production of upon addition of $\mathrm{Ca}^{++}$and $\mathrm{Mg}^{++}$.
\end{abstract}

Keywords: Bacillus sp., protease, soybean

\section{INTRODUCTION}

Proteases also known as peptidyl-peptide hydrolysis, constitute $60-65 \%$ of the global enzyme market (Banerjee et al., 1999; Genckel and Tari, 2006; Laxman et al., 2005). The applications of proteases include in the detergent, food, leather, meat tenderization industries. Proteases are also important tools in studying the structure of proteins and peptides. Besides that, they are also used in pharmaceuticals, medical diagnosis, and decomposition of gelatin on X-ray films as well as in textiles (Joo et al., 2002; Patel et al., 2005, Tari et al., 2006). Protease can be produced by all microorganisms, however, only microbes that produce a substantial amount of extra cellular protease have been exploited commercially. To date, the major proportion of the commercial alkaline protease are derived from Bacillus sp. (Joo et al., 2002; Manachini et al, 1998; Yang et al., 2000; Ito et al., 1998). The reason for this is their wide temperature and $\mathrm{pH}$ tolerance and stability (Genckel and Tari, 2006).

For the bulk production of commodity products like enzymes, the cost of the production media can substantially affect the overall process economics. Approximately $40 \%$ of the production cost of industrially important enzymes is estimated to derive from the cost of growth medium (Joo et al., 2002). Thus, the use of cost effective growth medium for the production of alkaline proteases from an alkalophilic Bacillus sp. is especially important, because these enzyme account for approximately $25 \%$ of the world wide enzyme consumption (Gessesse, 1997). In the current work, soybean meal (Glycine max) which is cheap and is commonly available was considered as a suitable

\section{*Corresponding author}

ingredient in the formulation of the production medium. Soybean meal is largely produced as a byproduct during oil extraction (Gattinger et al., 1990). Soybean which contains $40 \%$ of protein, $17 \%$ carbohydrate, $18 \%$ oil, traces of metals, moderate amount of vitamins and amino acids supplies almost all the nutrient required for the growth of Bacilli. Besides that, soybean also contains small amount of enzymes such as protease, urease and lipoxidase.

Our preliminary experiments revealed that protease secreted by this Bacillus sp.(SBP-29) is suitable for use in poultry processing industry degrading the turkey and chicken feathers which otherwise contribute to several tons of waste products. However, for the commercial exploitation and for extensive industrial evaluations, it was desirable to optimize the production on large scale using inexpensive media. In this paper, we describe a low cost medium for maximum production of an extra cellular alkaline protease from Bacillus $\mathrm{sp}$. and important biochemical properties.

\section{MATERIALS AND METHODS}

\section{Chemicals}

Casein and inhibitors of serine, cysteine and trypsin type proteases, soybean inhibitors and chelators of divalent cations (Ethylenedi aminetetra acetate (EDTA), were purchased from Sigma (St. Louis, USA). All other chemicals used were of analytical grade and were procured from local suppliers. 


\section{Organism and growth maintenance conditions}

Bacillus sp. (SBP-29), a potent protease producer was isolated from the soil by enrichment and selective screening on skim milk agar plate. The organism was cultivated at $37 \pm 1{ }^{\circ} \mathrm{C}$ in a bacteriological incubator for 24 $\mathrm{h}$ and subsequently maintained at $4{ }^{\circ} \mathrm{C}$ in a Biological Oxygen Demand (B.O.D) incubator (Yorko, Deluxe- 10) by routine transfers after every 15 days on nutrient agar slants at $\mathrm{pH} 7.0$.

\section{Protease production medium}

The modified basal medium used for protease production contained (g/L) Casamino acid (5); $\mathrm{NH}_{4} \mathrm{Cl}(3) ; \mathrm{KH}_{2} \mathrm{PO}_{4}$ (1.0); $\mathrm{K}_{2} \mathrm{HPO}_{4}$ (3.0); $\mathrm{Na}_{2} \mathrm{SO}_{4}$ (2.0); and $\mathrm{MgSO}_{4} .7 \mathrm{H}_{2} \mathrm{O}$ (0.10) with the $\mathrm{pH}$ of 7.0 . The production medium $(50 \mathrm{~mL})$ was inoculated with $2.0 \%$ of inoculum with $\mathrm{OD}_{660}$ of 0.65 . The culture was incubated at $37 \pm 1{ }^{\circ} \mathrm{C}$ at $200 \mathrm{rpm}$ in a incubator shaker (NBS Shaker, G-25R, Edison, USA). After the desired incubation period, the culture was centrifuged at $8000 \times g$ for 20 min at $4{ }^{\circ} \mathrm{C}$ (Sorvall, RC-5C plus, Du Pont, Germany). The supernatant obtained was used as protease source.

\section{Protease assay}

The protease activity was measured as described by Meyers and Ahearn (1976) with some modifications. 0.5 $\mathrm{mL}$ of glycine $\mathrm{NaOH}$ buffer ( $\mathrm{pH} 10,0.2 \mathrm{M}$ ) was added to $0.5 \mathrm{~mL}$ of appropriately diluted enzyme and was incubated with $1 \mathrm{~mL}$ of $1 \%$ casein solution (prepared in glycine $\mathrm{NaOH}$ buffer, $\mathrm{pH} 10$ ) for $15 \mathrm{~min}$ at $60^{\circ} \mathrm{C}$. The reaction was stopped by the addition of $4 \mathrm{~mL}$ of $5 \%(\mathrm{v} / \mathrm{v})$ trichloroacetic acid. The contents were centrifuged after 1 $\mathrm{h}$ at $3000 \times \mathrm{g}$ for $10 \mathrm{~min}$ and the filtrate was used for measuring protease activity on the basis of color change. $5 \mathrm{~mL}$ of $0.4 \mathrm{M}$ sodium carbonate solutions was added to 1 $\mathrm{ml}$ of the filtrate and was kept for $10 \mathrm{~min}$. Folin's Ciocalteau Phenol reagent of 1:1 dilution was added and kept in dark for $30 \mathrm{~min}$. The color change was determined at $660 \mathrm{~nm}$. One unit of protease was equivalent to the amount of enzyme required to release $1 \mathrm{mg} / \mathrm{mL} / \mathrm{min}$ of tyrosine under standard assay conditions.

\section{Effect of carbon and nitrogen sources}

The effect of carbon and nitrogen sources for protease production were determined using different simple and complex carbon sources consisting of glucose, fructose, galactose, starch, lactose, mannose, sucrose, sorbitol, mannitol, dextrin, malt extract, wheat bran and maize starch. Organic and inorganic nitrogen sources consists casein, casamino acid, skim milk, peptone, beef extract, yeast extract, CSL, soybean meal, $\mathrm{NH}_{4} \mathrm{Cl}, \mathrm{NH}_{4} \mathrm{NO}_{3}$ and $\mathrm{NaNO}_{3}$ were supplemented individually in the production medium for protease production from Bacillus sp. All these sources were replaced in the production medium at a concentration of $0.5 \%(\mathrm{w} / \mathrm{v})$ and $2.0 \%(\mathrm{w} / \mathrm{v})$ for carbon and nitrogen, respectively. Protease yield was determined after $48 \mathrm{~h}$ of incubation at $37^{\circ} \mathrm{C}$ under shaking condition of $200 \mathrm{rpm}$.

\section{Enzyme characterization}

The effect of temperature on the stability and activity of the protease was determined by incubating the enzyme at different temperature ranging from $10-90^{\circ} \mathrm{C}$. The $\mathrm{pH}$ stability and activity of the enzyme was tested at different $\mathrm{pH}$ 6-12 using phosphate buffer $\mathrm{pH} 6-8$; Tris- $\mathrm{HCl}$ bufferpH 9.0 ; Glycine $\mathrm{NaOH}$ buffer-10.0 and phosphate buffer for $\mathrm{pH}$ 11.0; $\mathrm{pH}$ 12.0. Every reaction mixture contained the same amount of protease and the reaction was performed under the same conditions accept for the $\mathrm{pH}$ value or temperature.

The effect of various inhibitors and chelators on protease activity was determined by incubating with the enzyme for $30 \mathrm{~min}$ at room temperature and the relative activity was determined by standard assay protocols. All the inhibitors were used at $1 \mathrm{mM}$ final concentration unless otherwise stated. The effect of metal ions of $1 \mathrm{mM}$ concentration on protease activity was determined by incubating the enzyme with different metal salts at room temperature for $1 \mathrm{~h}$ and thereafter the relative activities were determined under standard assay conditions. The enzyme assay was carried out in the presence of $\mathrm{Ca}^{++}$, $\mathrm{Cu}^{++}, \mathrm{Fe}^{++}, \mathrm{Ba}^{++}, \mathrm{Co}^{++}, \mathrm{Cd}^{++}, \mathrm{Mg}^{++}, \mathrm{Mn}^{++}, \mathrm{Zn}^{++}$and $\mathrm{Hg}^{++}$.

\section{Protease production in a fermentor system}

Cultivation of Bacillus sp. for protease production was also carried out in a $10 \mathrm{~L}$ fermentor (Bio-flow IV, NBS, USA) with a working volume of $7.5 \mathrm{~L}$. The medium was sterilized in situ at $121{ }^{\circ} \mathrm{C}$ for $20 \mathrm{~min}$ and was inoculated with appropriate size of the seed inoculum $\left(O D_{660 \mathrm{~nm}} \cong 0.600\right)$. The fermentation was carried out at $37 \pm 1{ }^{\circ} \mathrm{C}$ for $24 \mathrm{~h}$ with controlled $\mathrm{pH}$ at 7.0. The impeller speed was initially adjusted to $350 \mathrm{rpm}$ and compressed sterile air was sparged into the medium at constant rate of $0.5 \mathrm{vvm}$. The dissolved oxygen was not allowed to fall below a fixed set point of $25 \%$ by cascading. Samples were withdrawn periodically at an interval of $2 \mathrm{~h}$ and analyzed for protease production. The fermentation parameters, such as temperature, $\mathrm{pH}$, dissolved oxygen and airflow rate were continuously monitored using microprocessor-controlled probes.

\section{RESULTS AND DISCUSSION}

The selected strain, SBP-29 exhibited a large zone of hydrolysis on milk agar plate and was taken up for optimization of maximum production, scale up and protein characterization. The isolate was a Gram positive, motile, rod shaped bacterium and strictly aerobic. This isolate produced $440 \mathrm{U} / \mathrm{mL}$ of protease in the initial production medium. 


\section{Effect of carbon source on the protease production}

Bacillus sp. produced maximum protease in wheat bran (1373 U/mL) followed by glucose $(1100 \mathrm{U} / \mathrm{mL})$. However, carbon sources like sorbitol, mannitol and dextrin, drastically inhibit the protease production. Further optimization of the wheat bran concentration showed that wheat bran was the effective substrate for protease production among all the carbon sources tested and the yield was enhanced by two fold by the addition of $0.5 \%$ wheat bran ( $1374 \mathrm{U} / \mathrm{mL}$ ) when compared with a basal medium without bran ( $440 \mathrm{U} / \mathrm{mL}$ ) (Figure1).

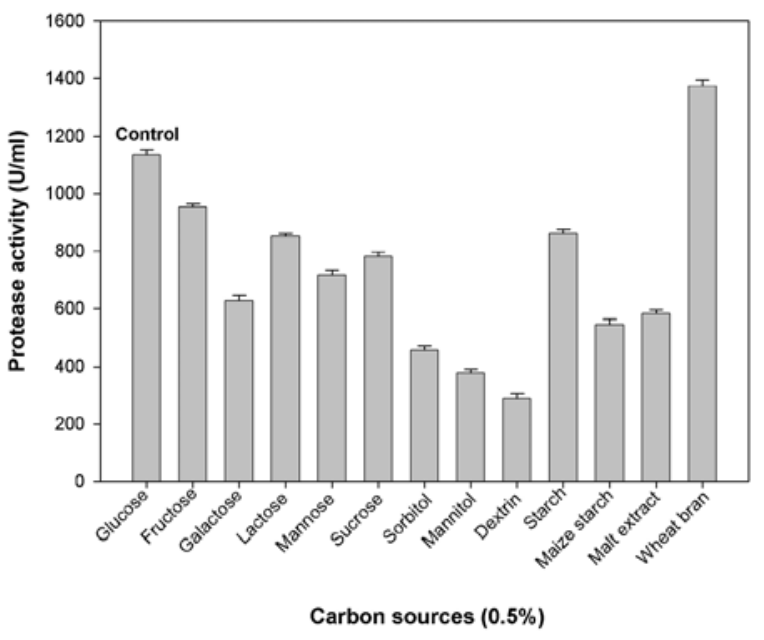

Figure 1: Effect of different carbon sources on protease production by Bacillus sp.

\section{Effect of nitrogen source on the protease production}

Bacillus sp. was grown in the presence of different (organic and inorganic) nitrogen sources, replacing the total nitrogen from the production medium with equivalent amount of nitrogen, in the presence of $0.5 \%$ wheat bran as carbon source. All the organic nitrogen sources used in the present study supported growth and production. Maximum production of protease $(2725 \mathrm{U} / \mathrm{mL})$ was observed with $2 \%$ soybean meal (Figure 2). This is followed by soyflour, casein, etc. Nilegaonkar et al. (2007) reported that the protease activity was highest with soybean meal (124.24 U/mL). Deshpande et al. (2004) also reported that soybean meal was used as an inducer for protease production from Conidiobolus coronatus. In case of inorganic nitrogen sources, except for sodium nitrate, none of the other three inorganic nitrogen source supported the growth. Our results are in accordance to the findings of Ferrero et al. (1996); Johnvesly and Naik (2000); Kole et al. (1988) who observed that inorganic nitrogen sources like ammonia are less favorable for the growth and enzyme production.

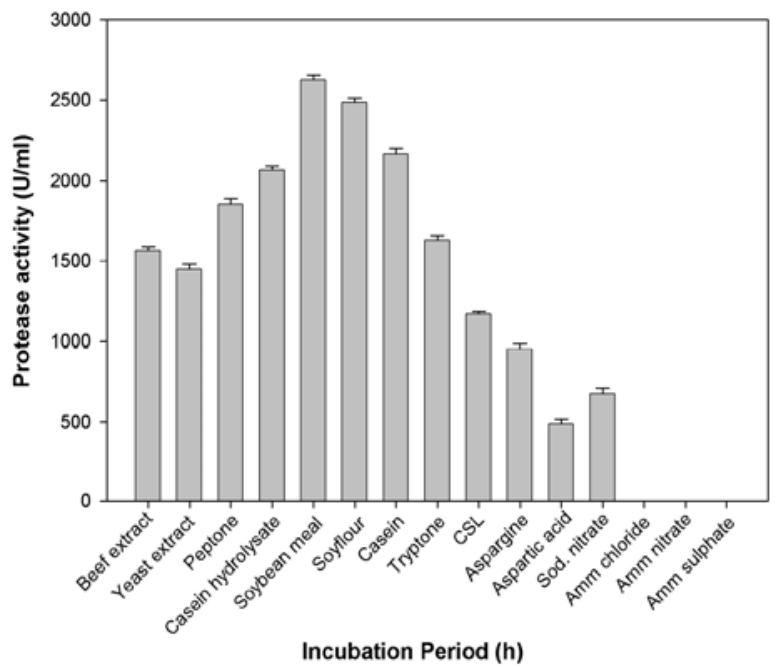

Figure 2: Effect of nitrogen source on protease production by Bacillus sp.

\section{Maximum enzyme production using soybean meal}

It is well documented in the literature that nitrogen is metabolized to produce primarily amino acid, nucleic acid, protein and cell wall components. These nitrogen sources have regulatory effect on the enzyme synthesis. Production of protease is highly dependent on the both carbon and nitrogen source available in the medium (Chu et al., 1992; Moon et al., 1991; Patel et al., 2005). Soybean meal is a source of both carbon and nitrogen. It is an inexpensive and readily available substrate. In the present study, as soybean meal was found to be best inducer, effect of soybean meal concentration $(0.5-3 \%)$ on protease production was studied. Results showed that the enzyme production reaches to $3021 \mathrm{U} / \mathrm{mL}$ with $1.5 \%$ soybean meal (Table 1). Similar finding had been reported by Joo et al. (2002), who observed that soybean meal at $1.5 \%$ concentration resulted in highest protease production in Bacillus horikoshii. Our study is further supported by the findings of Sutar et al. (1992); Laxman et al. (2005) who reported $4 \%$ and $2 \%$ soybean meal to be optimal for protease production from Aspergillus flavus and Conidiobolus coronatus.

Table 1: Effect of soybean meal concentration on protease produced by Bacillus sp. at $37^{\circ} \mathrm{C}$ and $\mathrm{pH} 7.0$

\begin{tabular}{cc}
\hline $\begin{array}{c}\text { Concentration of } \\
\text { Soybean (\% w/v) }\end{array}$ & Protease (U/mL) \\
\hline 0.5 & $1867 \pm 11$ \\
1.0 & $2637 \pm 09$ \\
1.5 & $3021 \pm 14$ \\
2.0 & $2634 \pm 08$ \\
2.5 & $1905 \pm 10$ \\
3.0 & $1346 \pm 09$ \\
\hline
\end{tabular}




\section{Temperature and pH stability of the enzyme}

The optimum temperature of the enzyme was found to be $60{ }^{\circ} \mathrm{C}$ (Figure 3 ) and the enzyme tolerance is between 20 $90{ }^{\circ} \mathrm{C}$, the enzyme was $90 \%$ stable up to $55^{\circ} \mathrm{C}$ after $1 \mathrm{~h}$ of incubation, however it showed a marked decrease over 60 ${ }^{\circ} \mathrm{C}$ within $30 \mathrm{~min}$ (Figure 4). The optimum $\mathrm{pH}$ of the enzyme is 9.0 (Figure 5). However, the enzyme was active up to $\mathrm{pH} 12.0$. However, the activity remains $77 \%$ at $\mathrm{pH} 12$ after $1 \mathrm{~h}$ of incubation (Figure 6). The high $\mathrm{pH}$ optimum is a feature of alkaline protease (Gessesse, 1997; Mehrotra et al., 1999; Jasvir et al., 1999, Joo et al., 2002).

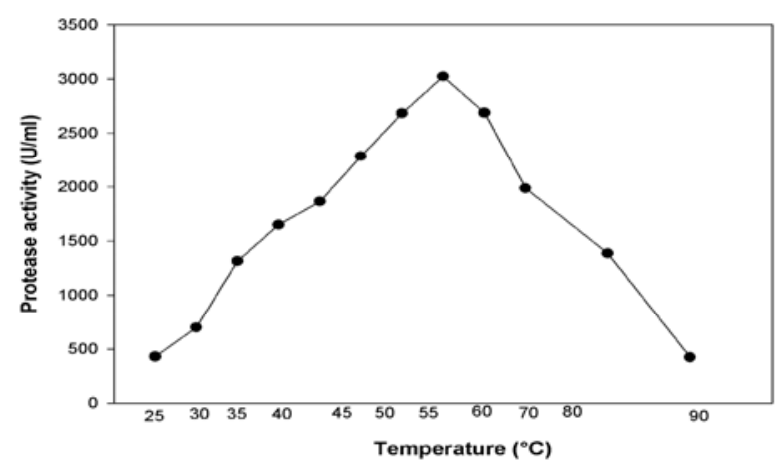

Figure 3: Temperature profile of the Bacillus sp. protease

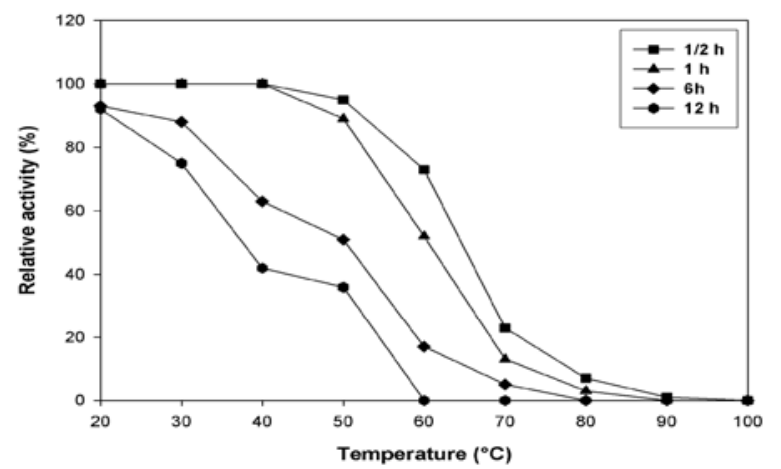

Figure 4: Temperature stability of alkaline protease produced by Bacillus sp.

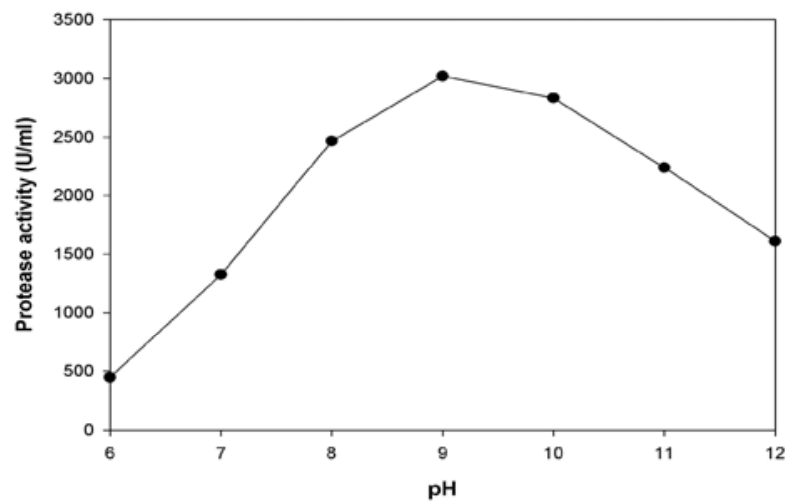

Figure 5: Optimum $\mathrm{pH}$ profile of the Bacillus sp. protease

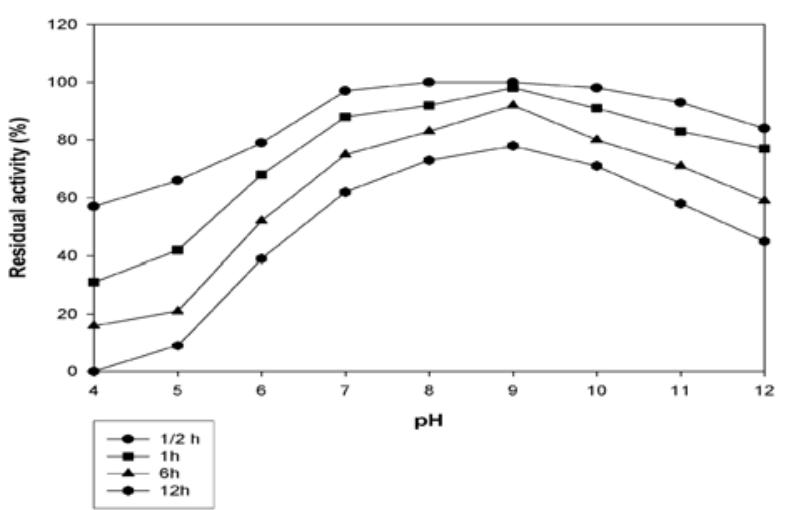

Figure 6: $\mathrm{pH}$ stability of the alkaline protease by Bacillus sp.

\section{Effect of inhibitors on protease synthesis}

The activity of the protease was completely inhibited in the presence of $1 \mathrm{mM}$ phenylmethylsulfonyl fluoride (PMSF), diodopropyl fluorophosphate (DFP) and lodoacetic acid. Inhibitors like cyanamide and $\mathrm{N}$-ethylmaleimide slightly inhibited the enzyme activity (Table 2). Several specific protease inhibitors such as bestatin, chymostatin and $N$ bromosuccinyl also inhibit the enzyme activity upto more than $90 \%$. PMSF is known to strongly inhibit the serine residue at the active site causing complete loss of enzyme activity (Huang et al., 2003; Tang et al., 2004). This inhibition profile suggests that the extracellular protease from Bacillus sp. belongs to a family of serine protease. Among the metal ions tested, $\mathrm{Ca}^{++}$and $\mathrm{Mg}^{++}$marginally stimulated the protease activity upto $15 \%$ at $1 \mathrm{mM}$ concentration (Table 3 ). These cations probably protect the enzyme against thermal denaturation and therefore maintain the active conformation of the enzyme at high temperature (Donaghy and Mc Kay, 1993). $\mathrm{Ag}^{+}$and $\mathrm{Co}^{++}$ inhibit the protease activity. Similar inhibitor and metal ion studies have been reported by Joo et al. (2002); Beg et al. (2003); Tang et al. (2004).

\section{Scale up of protease production in $10 \mathrm{~L}$ bioreactor}

Scale up studies were carried out in a $10 \mathrm{~L}$ bioreactor with a working volume of $7.5 \mathrm{~L}$. Protease production started early within $4 \mathrm{~h}$, however, there was no significant increase in the production up to $8 \mathrm{~h}$. This is because, at this time, the organism was in the exponential phase. A significant fall (below 25\%) in the dissolved oxygen was observed which was automatically maintained by an increase in the agitation from 300 up to $600 \mathrm{rpm}$. Similar has been observed by Laxman et al. (2005) who reported that $500 \mathrm{rpm}$ was suitable for the growth and protease activity. The exponential phase was followed by the stationary phase wherein maximum protease activity was observed resulting in $3208 \mathrm{U} / \mathrm{mL}$ of protease in $18 \mathrm{~h}$ (Figure 7). Thereafter, a decline in the protease 


\begin{tabular}{lc}
$\begin{array}{c}\text { Table 2: Effect of inhibitors on protease activity } \\
\text { Inhibitors (1mM) }\end{array}$ & $\begin{array}{c}\text { Relative } \\
\text { activity (\%) }\end{array}$ \\
\hline Control & 100 \\
$\beta$-mercaptoethanol & 113 \\
Antipain & 60 \\
Bromoacetic acid & 82 \\
Ethylene diamine tetra acetate & 64 \\
Dithiothrietol (DTT) & 77 \\
Cyanamide & 90 \\
Phenyl methyl sulphonyl Fluoride & No activity \\
(PMSF) & 95 \\
N-ethylmaleimide & 99 \\
N-Bromosuccinyl & No activity \\
diodopropyl & \\
(DFP) & 02 \\
lodoacetic acid & 11 \\
Bestatin & 05 \\
Chymostatin &
\end{tabular}

Table 3: Effect of metal ions on protease activity

\begin{tabular}{cc}
\hline Metal ions (1mM) & Relative activity (\%) \\
\hline Control & 100 \\
$\mathrm{Ca}^{++}$ & 116 \\
$\mathrm{Mg}^{++}$ & 110 \\
$\mathrm{~Pb}^{++}$ & 90 \\
$\mathrm{Ba}^{++}$ & 85 \\
$\mathrm{Mn}^{++}$ & 78 \\
$\mathrm{Zn}^{++}$ & 75 \\
$\mathrm{Cu}^{++}$ & 69 \\
$\mathrm{Fe}^{++}$ & 48 \\
$\mathrm{Co}^{++}$ & 33 \\
$\mathrm{Ag}^{++}$ & 16 \\
$\mathrm{Hg}$ & 9 \\
$\mathrm{EDTA}$ & 85 \\
\hline
\end{tabular}

Note: Control: Protease activity $3021(\mathrm{U} / \mathrm{mL})$

production was observed in the bioreactor. Moon et al. (1991); Chu et al. (1992); Gupta et al. (2002) have also reported a similar cessation in protease production once a maximum amount of the enzyme is produced during the run. Although, there are several theories such as autoproteolysis (Jang et al., 2001) and protease degradation by some proteolytic activity on the cell surface on nitrogen starved cells in the fermentation broth have been put forward (Chu et al., 1992; Beg et al., 2003), however, the exact mechanism is yet to be clearly known. During the fermentation, the aeration rate also influences the mixing of media components and thus affects the nutrient availability to microorganisms (Moon et al., 1991; Chu et al., 1992). In the present model, the high agitation rate (>200 rpm) favored maximum production and a decrease in the agitation rate drastically lowered the total protease yield. Protease production at high agitation rate up to 360-600 rpm has been reported by Moon et al. (1991) with B. firmus and by Jang et al. (2001) while working with Bacillus sp B21-2. Similar observation has been found in the present investigation, where when the agitation rates increases from 350 to $700 \mathrm{rpm}$ the organism grows at a fast rate achieving maximum protease $(3978 \mathrm{U} / \mathrm{mL})$ in a minimal time $18 \mathrm{~h}$ in a bioreactor.

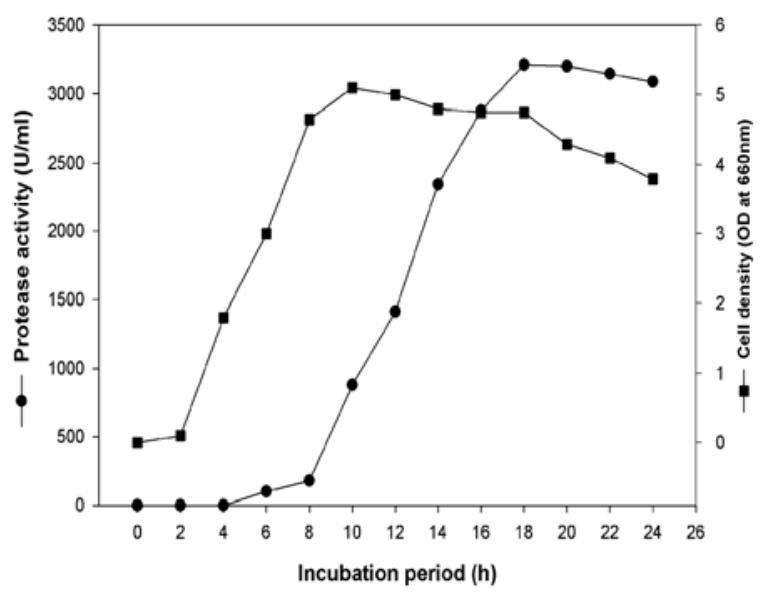

Figure 7: Fermentation profile of the protease produced by Bacillus sp.

\section{CONCLUSIONS}

Bacillus sp. (SBP-29) produces high levels $(3208 \mathrm{U} / \mathrm{mL}$ ) of an extracellular alkaline serine protease which has a $\mathrm{pH}$ optima of 9.0 and temperature optima of $60^{\circ} \mathrm{C}$. Based on optimization studies, it was ascertained that soybean meal is the most effective substrate for protease production. Moreover, soybean meal is an inexpensive nitrogen source as is produced as a byproduct during oil extraction. From the present investigation, it is envisaged that this isolate can be potential source of alkaline protease for use as additive in industrial application such as poultry processing industry. This protease has a good stability at high alkaline $\mathrm{pH}$ value and broad heat stability thereby permitting its wide biotechnological application potentials to be exploited in many industries as an environmentally benign product.

\section{ACKNOWLEDGEMENT}

Saurabh Saran and Jasmine Isar acknowledge with thanks to the Council of Scientific and Industrial Research (CSIR), New Delhi, Government of India, for the award of a Senior Research Fellowship.

\section{REFERENCES}

Banerjee, C.V., Sani, R.K., Azmi, W. and Soni, R. (1999). Thermostable alkaline protease from Bacillius 
brevis and is characterized as a laundry determine additive. Process Biochemistry 35: 213 - 219.

Beg, Q.K., Sahai, V. and Gupta, R. (2003). Statistical media optimization and alkaline protease production from Bacillus mojavensis in a bioreactor. Process Biochemistry 38: $1-7$.

Chu, I.M., Lee, C. and Li, T.S. (1992). Production and degradation of alkaline protease in batch cultures of Bacillus subtilis ATCC 14416. Enzyme and Microbiol Technology 14: 755 - 761.

Donaghy, J.A. and Mc Kay, A.M. (1993). Production and properties of an alkaline protease by Aureobasidium pullulans. Journal of Applied Bacteriology 74: 662 666.

Ferrero, M.A., Cartro, G.R., Abate, C.M., Baigori, M.D. and Sineriz, F. (1996). Thermostable alkaline protease of Bacillus licheniformis MIR 29: isolation, production and characterization. Applied Microbial Biotechnology $327-322$.

Gattinger, L.D., Duvnjak, Z. and Khani, A.W. (1990). The use of canola meal as a substrate for xylanse production by Trichoderma reesei. Applied Microbial Biotechnology 33: $21-25$.

Genckal, H. and Tari, C. (2006). Alkaline protease production from alkalophilic acillus sp. isolated from natural habitats. Enzyme and Microbial Technology 39: $703-710$.

Gessesse, A. (1997). The use of nugmeal as low-cost substrate for the production of alkaline protease by the alkaliphilic Bacillus sp. AR-009 and some properties of the enzyme. Bioresource Technology 62: $59-61$.

Gupta, R., Beg, Q. K., Khan, S. and Chauhan, B. (2002). An overview on fermentation, downstream processing and properties of microbial alkaline proteases. Applied Microbial Biotechnology 60: 381 395.

Ito, S., Kobayashi, T., Ara, K., Ozaki, K., Kawai, S. and Hatada, Y. (1998). Alkaline detergent enzymes from alkaliphiles: enzymatic protiens, genetics, and structures Extremophiles 2: 185 - 190.

Jang, J.W., Jun, H. K., Kim, E. K., Jang, W.H., Kang, J. H. and Yoo, O. J. (2001). Enhanced thermal stability of an alkaline protease, prP, isolated from a Pseudomonas sp. by mutation at an autoproteolysis site, Ser-331. Biotechnology and Applied Biochemistry 34: 81 - 84.

Jasvir, S., Gill, N., Devashahayam,G. and Sahoo. D.K. (1999). Studies on alkaline protease produced by Bacillus sp. NG 312. Applied and Environmental Microbiology 6: 57 - 63.

Johnvesly, B. and Naik, G.R. (2000). Studies on production of thermostable alkaline protese from thermophilic and alkalophilic Bacillus sp. JB-99 in a chemically defined medium. Process Biochemistry 37: 39 - 144.

Joo, H.S., Kumar, C.G., Park, G.C., Kim, K.M., Paik, S.R. and Chang, C.S. (2002). Otimization of the production of an extracellular alkaline protease from
Bacillus horikoshii. Process Biochemistry 38:155 159.

Kole, M.M., Draper, I. and Gerson, D.F. (1988). Production of protease by Bacillus subtilis using simultaneous control of glucose and ammonium concentrations. Journal of Chemical Technology and Biotechnology 41: 197- 206.

Laxman, R.S., Sonawane, A.P., More, S.V., Rao, B.S. Rele, M.V. Jogdand, V.V., Deshpande, V.V. and Rao, M.B. (2005). Optimization and scale up of production of alkaline protease from Conidiobolus coronatus . Process Biochemistry 40: 3152 - 3158.

Manachini, P.L. and Fortina, M.G. (1998). Production in a sea -water of thermostable alkaline proteases by a halotolerant strain of Bacillus licheniformis. Biotechnology letters 20: 565 - 568.

Mehrotra, S., Pandey, P.K., Gaur, R. and Dharmwal, N.S. (1999). The production of alkaline protease by Bacillus species isolate. Bioresource Technology 67: $201-203$.

Meyers, S.P. and Ahearn, D.G. (1977). Extracelllular proteolysis by Candida lipolytica. Mycologia 69: 646651.

Moon, S.H. and Parulekar, S.J. (1991). Parametric study of protein production in batch and fed batch cultures of Bacillus firmus. Biotechnology and Bioengeneering 37: 467 - 483.

Patel, R., Dodia, M. and Singh S.P. (2005). Extracellular alkaline protease from a newly isolated haloalkaliphilic Bacillus sp.: Production and optimization. Process Biochemistry 40: 3569 - 3575.

Sutar, I.I., Srinivasan, M.C. and Vartak, H.G. (1992). Production of alkaline proteinase from Conidiobolus coronatus and its use to resolve DL- phenylanine and DL- phenyl glycine. World Journal Microbiology \&. Biotechnology 8: 254 - 258.

Tang, X.M., Lakay, F.M., Shen, W., Shao, Wei, L., Fang, H.F., Prior, B.A., Wang, X.Z. and Zhuge, J. (2004). Purification and characterization of an alkaline protease used in tannery industry from Bacillus licheniformis. Biotechnology Letters 26: 1421 - 1424.

Tari, C., Genckal, H. and Tokatali, F. (2006). Optimization of a growth medium using a statistical approach for the production of alkaline protease from a newly isolated Bacillus sp. L 21. Process Biochemistry 41: $659-665$.

Yang, J.K. Shih, I.L., Tzeng, Y.M. and Wang, S.L. (2000). Production and purification of proteases from a Bacillus subtilis that can deproteinize crustaceans wastes. Enzyme and Microbial Technology 26: 406 413. 